\title{
Concurrent overexpression of RET/PTC1 and TTF1 confers tumorigenicity to thyrocytes
}

\section{Toyoshi Endo* and Tetsuro Kobayashi*}

Third Department of Internal Medicine, Interdisciplinary Graduate School of Medicine and Engineering, University of Yamanashi, Chuo City, Yamanashi 409-3898, Japan

*(T Endo and T Kobayashi contributed equally to this work)
Correspondence should be addressed to T Endo

Email endot@yamanashi.ac.jp

\begin{abstract}
A variant located on 14q13.3 nearest to thyroid transcription factor-1 (TTF1) predisposes individuals to thyroid cancer, but whether this variant is related to the RETIPTC rearrangement associated with human papillary thyroid carcinomas (PTCS) is unknown. The aims of this study were to investigate the effects of RET/PTC1 on the expression of thyroid-specific genes in thyrocytes and their relationship with malignant transformation of the thyrocytes. In the absence or presence of TSH, an extracellular signal-regulated kinase was phosphorylated in FRTL5 cells that stably expressed RET/PTC1, and these cells grew independently of TSH. FRTL (RET/PTC1) cells produced $566 \%$ more thyroglobulin mRNA and $474 \%$ more $\mathrm{Na}+/ \mathrm{l}$ - symporter mRNA than did the control FRTL (pCDNA) cells. FRTL (RET/PTC1) cells expressed $468 \%$ more Ttf1 mRNA than did FRTL (pCDNA) cells, but these two cell types did not differ significantly with respect to Pax8 or Ttf2 mRNA levels. When FRTL (RET/PTC1) cells and FRTL (pcDNA), cells were injected into each of nine nude mice, each mouse developed a single tumor at the site of FRTL (RET/PTC1) cell injection; in contrast, tumor formation never occurred at sites of FRTL (CDNA) cells injection. Tumors resulting from FRTL (RET/PTC1) cells retained ${ }^{125}$-uptake activity; moreover, the cells invaded into surrounding skeletal muscle. When overexpression of Ttf1 in FRTL (RET/PTC1) cells was silenced, the cells completely lost their tumorigenic potential. Exogenous TTF1 CDNA enhanced the tumorigenicity of BHP18-21v cells, human PTC cells that express RET/PTC1, in nude mice. These results indicated that concurrent overexpression of RET/PTC1 and TTF1 confers tumorigenicity to FRTL5 and BHP18-21v cells in nude mice.
\end{abstract}
Key Words
- RET/PTC
- thyrocytes
- thyroid transcription factor-1
- tumorigenesis

Endocrine-Related Cancer (2013) 20, 767-776

\section{Introduction}

Papillary thyroid carcinomas (PTCs) are the most frequent cancers of the thyroid gland, and they are usually well differentiated given their ability to i) take up iodine, ii) secrete thyroglobulin (TG), and iii) be responsive to thyroidstimulating hormone (TSH; Nikiforov \& Nikiforova 2011).

The RET/PTC rearrangement and the $B R A F^{\mathrm{V} 600 \mathrm{E}}$ point mutation are the two most common genetic alterations associated with PTCs; the prevalence of RET/PTC varies from 2.5 to $78 \%$ (Zou et al. 1994, Nikiforov et al. 1997), and the prevalence of $B R A F^{\mathrm{V} 600 \mathrm{E}}$ varies from 23 to $62 \%$ (Xing et al. 2005, Fugazzola et al. 2006).

Rearrangements of the RET gene can cause recombination of sequences encoding the intracellular kinase domain of RET with a heterologous gene and 
thereby generate a chimeric oncogene that induces RAS-dependent activation and consequent ERK activation (Melillo et al. 2005). However, constitutive activation of ERK caused by a RET/PTC oncogene may or may not be sufficient to induce all hallmarks of cancer in vivo. Santoro et al. (1996) found that some RET/PTC1 transgenic mice developed thyroid tumors, but others developed only thyroid hyperplasia. Knostman et al. (2007) reported that doxycycline-induced expression of RET/PTC1 led to ERK phosphorylation in mice that carried a doxycyclineregulated RET/PTC1 transgene; however, thyroid lesions were not found in any of these mice.

These results indicate that oncoproteins such as RET/PTC activate the MEK/ERK cascade, which then promotes an initial wave of dramatic cell proliferation that, in turn, initiates tumor development, but subsequent development of a solid cancer requires an additional unknown lesion or alteration (Pritchard et al. 2007).

Gudmundsson et al. (2009) recently conducted a genome-wide association study (GWAS) of thyroid cancer cases; they found that a variant predisposes individuals from European populations to thyroid cancer; this variant is located on 14q13.3 near thyroid transcription factor-1 (TTF1), which is also called NKX2.1. TTF1 and PAX8 are master regulators of thyroid-specific gene expression. For example, they regulate TG, NIS (SLC5A5), and TSHR; moreover, they play pivotal roles in the development of thyroid glands (Sinclair et al. 1990, Silberschmidt et al. 2011). Therefore, the GWAS findings may be relevant to the pathogenesis of PTCs. However, whether relationships between the variant at 14q13.3 and the genetic alterations in PTCs (e.g., RET/PTC rearrangements) exist is unclear.

To assess whether there are important interactions between the $14 \mathrm{q} 13.3$ variant and RET/PTC rearrangements, we expressed RET/PTC1 in FRTL5 cells, functional thyroid epithelial cells, and studied the effects of RET/PTC1 on the expression of thyroid-specific genes with a particular focus on the expression of $T t f 1, T t f 2$, and Pax8, and their relationship with tumorigenicity of the cells. Further, TTF1 cDNA was introduced into BHP18-21v cells, which are human PTC cells, to examine the effects of TTF1 on tumorigenicity of these cells.

\section{Materials and methods}

\section{Cells, tissues, and animals}

FRTL5 cells (CRL8395, ATCC, Manassas, VA, USA) were cultured in Ham F12 medium that contained $5 \mathrm{H}$ (insulin $10 \mathrm{ng} / \mathrm{ml}$, cortisol $0.4 \mathrm{ng} / \mathrm{ml}$, transferrin $5 \mu \mathrm{g} / \mathrm{ml}$,
glycyl-L-histidyl-L-lysine $10 \mathrm{ng} / \mathrm{ml}$, and somatostatin $10 \mathrm{ng} / \mathrm{ml}$ ) and $5 \%$ calf serum with or without $10 \mathrm{mU} / \mathrm{ml}$ TSH (Sigma-Aldrich, Inc.) (Endo et al. 1990). The cells grew in a TSH-dependent manner and expressed seven thyroidspecific genes - Ttf1, Ttf2, Pax8, $T$ g, thyroid peroxidase (Tpo), $\mathrm{Na}+/ \mathrm{I}-$ symporter (Nis), and Tsh receptor (Tshr). BHP18$21 \mathrm{v}$ cells were isolated from BHP18-21 cells, which are human thyroid papillary cancer cells that express RET/PTC1 (Ohta et al. 1997); BHP18-21v cells were cultured in RPMI1640 containing $10 \%$ FCS, and they expressed PAX 8 but not TTF1, TTF2, TG, TPO, NIS, or TSHR. This expression profile is unique to BHP18-21v cells among BHP cell lines; therefore, the BHP18-21v cells we used were free from contamination. BRL-3A cells (CRL-1442, ATCC) were cultured in Ham F12 medium that contained 5\% FCS. A 5-bromo-2'-deoxyuridine (BrdU) incorporation assay (BrdU labeling and detection kit, Roche Diagnostics) was used to monitor cell proliferation. Normal human thyroid tissues were obtained from surgical specimens taken from patients with papillary thyroid cancer; each patient gave written informed consent. Male Balb/c nude mice (aged 12 weeks) were obtained from CLEA Japan, Inc., Tokyo, Japan. Each mouse was specific pathogen free and checked for pathogens once every 2 months. All studies performed were approved by the Animal Research Committee at the University of Yamanashi.

\section{Plasmid construction and transfection}

cDNAs were reverse transcribed from mRNA templates that had been isolated from BHP18-21v cells. Using this cDNA sample as template, RET/PTC1 cDNAs were PCR amplified with the following primers: sense, 5'-CTCCTCCTCCTTTCCCAGCC-3', and antisense, 5'-GCTCGGCCAATGTGACGTTCAC-3'. Amplified cDNAs were first ligated into a pCR2 vector (Invitrogen Co.) and then isolated insert cDNA was ligated into the KpnI/NotI site of pcDNA3.1-hygro (Invitrogen Co.). Human TTF1 cDNAs were cloned from human thyroid carcinoma lambda gt11 cDNA library (HL1009, Clontech Lab., Inc.), and an Eco RI insert that contained the full coding sequence $(1.4 \mathrm{~kb})$ was ligated into pcDNA3.1zeo. Plasmid DNA $(1 \mu \mathrm{g})$ was introduced into FRTL5 or BHP18-21v cells with the Gene Pulser (Gene Pulser Xcell; Bio-Rad) at $250 \mathrm{~V}-750 \mu \mathrm{F}$. Stable transformants were selected by adding $300 \mu \mathrm{g} / \mathrm{ml}$ hygromycin B (Wako Pure Chemicals, Inc., Ltd., Osaka, Japan) or $100 \mu \mathrm{g} / \mathrm{ml}$ Zeocin (Life Technologies Co.) to the culture medium. TTF1 siRNA was expressed in cells from a pSilencer 4.1-CMV neo construct (Applied Biosystems, Inc.); to generate this TTF1 siRNA construct, two

Published by Bioscientifica Ltd. 
oligonucleotides - 5'-GATTCACACGACTCCGTTCTCAGTTTCAAGAGAACTGACAACGGAGTCGTGTGCA-3' and 5'-AGCTTGCACACGACTCCGTTGTCAGTTCTCTTGAAACTGAGAACGGAGTCGTGTG-3' (Kolla et al. 2007) - were annealed and ligated into the BamH1/HindIII site of pSilencer 4.1-CMV neo (Applied Biosystems, Inc.) (pSilencer-TTF1). The construct or the pSilencer 4.1-CMV neo-negative control was introduced into cultured cells. Stable transformants were selected by adding $300 \mu \mathrm{g} / \mathrm{ml}$ geneticin (Sigma-Aldrich, Inc.) to the culture medium.

\section{Quantitative PCR}

The Rotor-Gene Q (Qiagen, Inc.) and 13 TaqMan probes (Applied Biosystems, Inc.) - rat Tg (Rn01458686_A1), rat Nis (Rn01420249_g1), rat Tshr (Rn00563612_A1), rat Ttf1 (Rn01512482_A1), rat Ttf2 (Foxe1) (Rn00594363_s1), rat Pax8 (Rn00579743_A1), rat Gapdh (Rn01775763_g1), human TTF1 (Hs00968940_m1), human TG (HsO0 174974_m1), human thyroid peroxidase (TPO) (HsOO 892519_m1), human NIS (Hs00166567_m1), human RET (Hs04259657_s1), and human GAPDH (Hs02758991_g1) - were used to perform quantitative PCR. Assays for each gene were carried out in triplicate, and transcript levels of thyroid-specific mRNA were normalized to those of GAPDH (human) or Gapdh (rat). Expression of GAPDH or Gapdh from the samples was within \pm 2 cycle number of threshold $(\mathrm{Ct})$.

\section{${ }^{125}$ I-uptake assay and TSH binding activity}

The ${ }^{125}$ I-uptake by FRTL5 cells was measured as described previously (Endo et al. 1996). ${ }^{125}$ I scintigraphy of the tumors formed in nude mice was performed by injecting $\mathrm{Na}^{125}$ I into the peritoneal space (Endo \& Kobayashi 2010). Radioactivity was monitored with a BAS2500 image analyzer (Fuji Film Co., Tokyo, Japan). ${ }^{125}$ I-TSH binding activity in each cell population was measured using ${ }^{125}$ I-bovine TSH (Cosmic Co., Tokyo, Japan) and methods described by Mizutori et al. (2008).

\section{Statistical analysis}

The Student's t-test and one-way ANOVA were used to assess the statistical differences between groups.

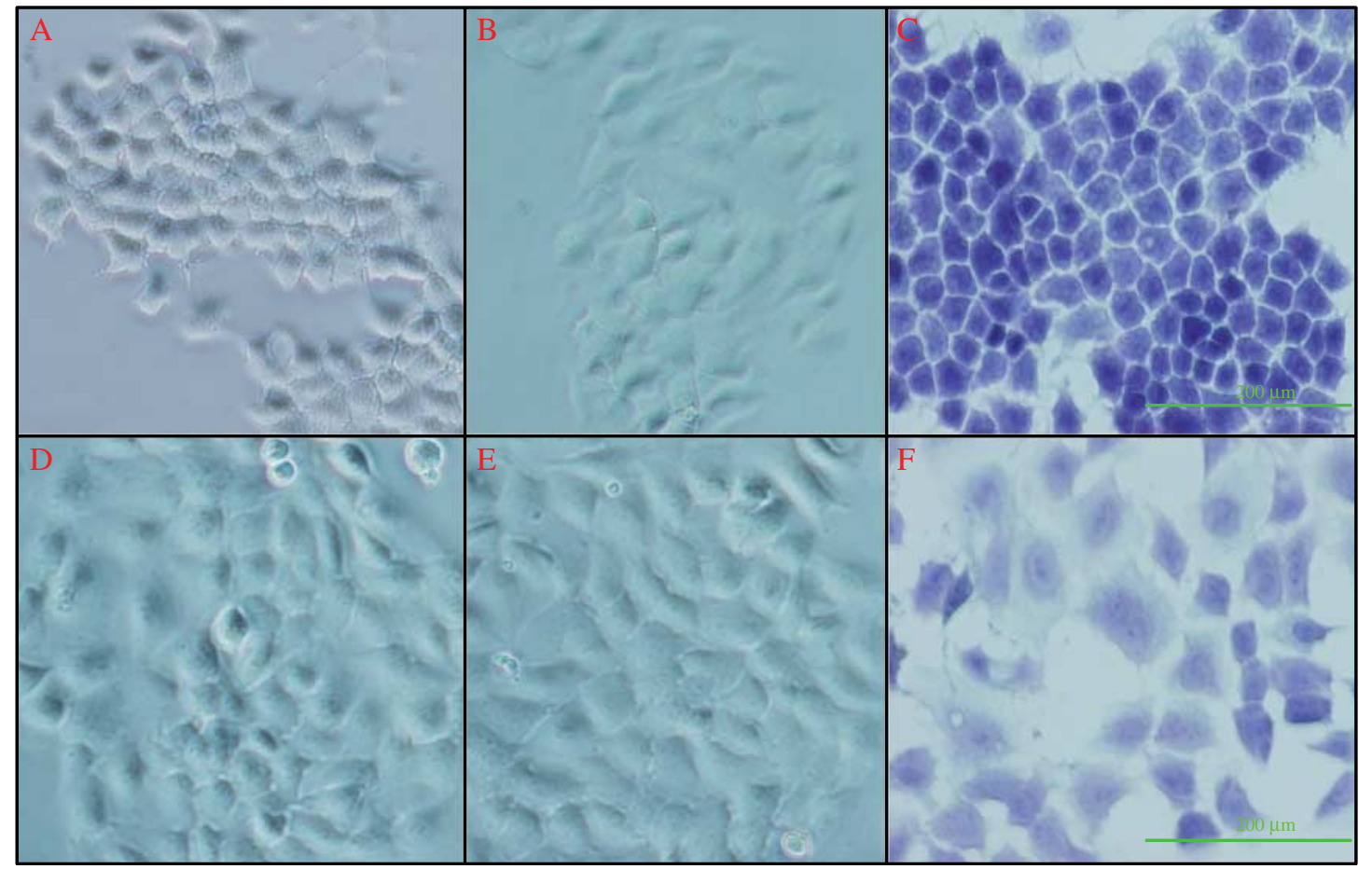

\section{Figure 1}

Morphology of FRTL (pcDNA) and FRTL (RET/PTC1) cells. Phase-contrast images of FRTL ( $p C D N A$ ) cells cultured for 6 days in the presence of $1 \mathrm{mU} / \mathrm{ml}$ TSH (A) or absence of TSH (B). Hematoxylin-eosin-stained FRTL (pcDNA) cells cultured in the presence of TSH (C). Phase-contrast images of FRTL
(RET/PTC1) cells cultured for 6 days in the presence of $1 \mathrm{mU} / \mathrm{ml}$ TSH (D) or absence of TSH (E). Hematoxylin-eosin-stained FRTL (RET/PTC1) cells cultured in the presence of TSH (F). Scale bars, $100 \mu \mathrm{m}$. http://erc.endocrinology-journals.org DOI: 10.1530/ERC-13-0310
(C) 2013 The authors Printed in Great Britain
Published by Bioscientifica Ltd. 


\section{Results}

\section{Effects of RET/PTC1 on the morphology of FRTL5 cells}

In the presence of TSH, FRTL5 cells transfected with the empty pcDNAhygro vector (FRTL (pcDNA) cells) were small and round and their cellular borders were well

A

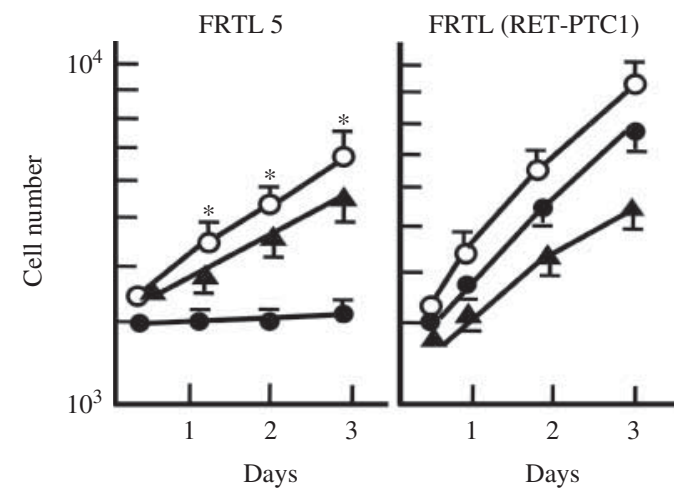

B

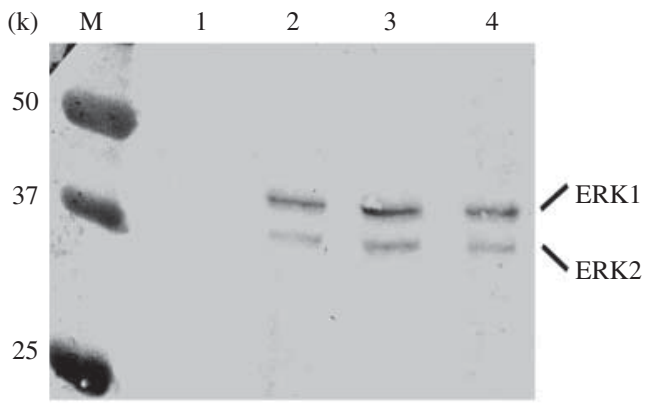

C



D



http://erc.endocrinology-journals.org DOI: 10.1530/ERC-13-0310 defined (Fig. 1A). When TSH was withdrawn from the medium, these control cells became flattened and the cell borders became obscured (Fig. 1B). We transfected pcDNAhygro-RET/PTC1 into FRTL5 cells and established stable lines (FRTL (RET/PTC1) cells). Quantitative RT-PCR using the plasmid DNA as a standard had revealed that $(4 \pm 0.6) \times 10^{5}$ copies $/ \mu$ g RNA were transfected into the cells. When compared with FRTL (pcDNA) cells, FRTL (RET/PTC1) cells were enlarged and flattened even in the presence of TSH, and their cellular borders were obscured regardless of the presence or absence of TSH (Fig. 1D and E). FRTL (RET/PTC1) cells and control cells were stained with hematoxylin; the nuclei of the FRTL (RET/PTC1) cells were irregularly shaped and larger than those of FRTL (pcDNA) cells (Fig. 1C and F). The nuclei of FRTL (RET/PTC1) contained more nucleoli than did those of FRTL (pcDNA) cells (Fig. 1F).

\section{Effects of RET/PTC1 on FRTL5 cell proliferation and function}

Proliferation of FRTL (pcDNA) cells depends on TSH, and addition of dibutyryl cAMP mimics the effect of TSH (Fig. 2A; Vitti et al. 1983). However, there was no significant difference in growth of FRTL (RET/PTC1) cell cultured in the presence or absence of TSH (Fig. 2A). FRTL (RET/PTC1) cells were able to proliferate even in the absence of TSH; the doubling time of the transformed cells was about $18 \mathrm{~h}$, which was shorter than that of FRTL (pcDNA) cells ( $24 \mathrm{~h}$ ). Extracellular signal-regulated kinase (ERK) 1 and ERK2 in FRTL (pcDNA) cells were

\section{Figure 2}

Effects of RET/PTC1 on FRTL5 cell proliferation and function. (A) Growth curves of cultures of FRTL5 cells stably transfected with pCDNAhygro (FRTL (pcDNA)) (FRTL, left panel) or with pcDNA-RET/PTC1 (FRTL (RET/PTC1), right panel) in the presence (open circle-open circle) or absence (closed circleclosed circle) of $1 \mathrm{mU} / \mathrm{ml} \mathrm{TSH}$ or in the presence of closed triangle-closed triangle: $1 \mathrm{mM}$ dibutyryl CAMP. Data are mean \pm s.E.M. of three independent experiments. ${ }^{*} P<0.01, \mathrm{TSH}(+)$ vs TSH $(-)$. (B) Western blot analysis of ERK phosphorylation. FRTL ( $p C D N A$ ) cells or FRTL (RET/PTC1) cells were cultured in the absence of TSH for 7 days, and then TSH $(1 \mathrm{mU} / \mathrm{ml})$ was added to the culture medium. FRTL (pcDNA) cells before (lane 1 ) and $3 \mathrm{~min}$ after the addition of TSH (lane 2). FRTL (RET/PTC1) cells before (lane 3 ) and $3 \mathrm{~min}$ after the addition of TSH (lane 4). M, molecular weight marker. (C) TSH binding activities of FRTL (RET/PTC1) cells and FRTL (pCDNA) cells. TSH binding activities of FRTL (RET/PTC1) cells (closed circle-closed circle), FRTL (pcDNA) cells (open circle-open circle), or BRL-3A rat liver cells (closed square-closed square) were studied using ${ }^{125} \mathrm{I}-\mathrm{TSH}$ as a tracer. Data are mean \pm s.E.M. of triplicate wells of cells. (D) lodide-uptake activities of FRTL (RET/PTC1) cells (closed circle-closed circle), FRTL (pcDNA) cells (open circleopen circle), or BRL-3A rat liver cells (closed square-closed square). Data are mean \pm s.E.M. of triplicate wells of cells.

Published by Bioscientifica Ltd. 
phosphorylated only after the addition of TSH (lane 2), but both proteins were phosphorylated in the presence and in the absence of TSH in FRTL (RET/PTC1) cells (lanes 3-4) (Fig. 2B). FRTL (pcDNA) cells showed high-affinity TSH binding activity $(\mathrm{Ka}=24 \mu \mathrm{U} / \mathrm{ml})$. FRTL (RET/PTC1) cells also showed high-affinity TSH binding activity, but total binding activity of FRTL (RET/PTC1) cells was about 30\% of that of FRTL (pcDNA) cells (Fig. 2C). In spite of the decreased TSH binding activity, ${ }^{125}$ I-uptake activity of FRTL (RET/PTC1) cells was about $300 \%$ of that of FRTL (pcDNA) cells (Fig. 2D).

\section{Effects of RET/PTC1 on the expression of genes encoding thyroid-specific proteins in FRTL5 cells}

We used quantitative RT-PCR to measure the expression of thyroid-specific mRNAs, such as $T g$, Nis, or Tshr in FRTL (RET/PTC1) cells. When target-gene expression in FRTL (pcDNA) cells was defined as 1.0, expression of $\mathrm{Tg}$ and $\mathrm{Nis}$ mRNAs in FRTL (RET/PTC1) cells was 5.66 and 4.74 respectively; in contrast, expression of Tshr mRNAs in FRTL (RET/PTC1) cells was 0.26 (Table 1).

Expression of $T g$ and Nis mRNAs in FRTL (RET/PTC1) cells differed significantly from that in FRTL (pcDNA) cells; therefore, we studied the effect of RET/PTC1 on expression of three genes encoding thyroid-specific transcription factors - Ttf1, Ttf2, and Pax 8 - in FRTL (RET/PTC1) and FRTL (pcDNA) cells. Expression Ttf1 mRNA was significantly higher $(4.68$-fold, $P<0.01)$ in FRTL (RET/PTC1) cells than in FRTL (pcDNA) cells. However, expression of Ttf 2 and Pax 8 did not differ significantly between FRTL (RET/PTC1) cells and FRTL (pcDNA) cells (Table 1). These results indicated that RET/PTC1 altered the expression level of $T t f 1$, which increased gene expression of $T g$ and Nis in FRTL5 cells.

Table 1 Effects of RET-PTC1 on the expression of thyroidspecific genes in FRTL5 cells

\begin{tabular}{|c|c|c|}
\hline & FRTL5 (pcDNA) & FRTL5 (RET-PTC1) \\
\hline Tg/Gapdh & 1.00 & $5.66 \pm 0.25 *$ \\
\hline Nis/Gapdh & 1.00 & $4.74 \pm 0.25 *$ \\
\hline Tshr/Gapdh & 1.00 & $0.26 \pm 0.04 *$ \\
\hline Ttf1/Gapdh & 1.00 & $4.68 \pm 0.34 *$ \\
\hline Ttf2/Gapdh & 1.00 & $0.97 \pm 0.24$ \\
\hline Pax8/Gapdh & 1.00 & $1.28 \pm 0.34$ \\
\hline
\end{tabular}

Data are mean + S.E.M. of three independent experiments. $* P<0.01$. ${ }^{a}$ Expression of each gene of the interest in FRTL (pcDNA) cells was set as 1.0 for comparison with the respective gene in FRTL5 (RET-PTC1) cells.

\section{Tumorigenicity of FRTL (RET/PTC1) cells}

We transplanted FRTL (RET/PTC1) cells into subcutaneous tissues on the right side of the backs of Balb/c nude mice; as controls, FRTL (pcDNA) cells were transplanted into subcutaneous tissues on the left side of the back of each mouse. After 2 months, tumor formation was evident at the site of FRTL (RET/PTC1) cell injection in six of ten mice, but one mouse did not have a tumor form at the site of FRTL (pcDNA) cell injection. By 4 months after injection, each mouse $(n=9)$ had developed a tumor at the site of FRTL (RET/PTC1) cell injection, and the mean of the maximum tumor diameter was $24 \pm 4.5 \mathrm{~mm}$ (Fig. 3A). By contrast, no tumor formation was evident at sites of FRTL (pcDNA) cell injection even 4 months after injection (Table 2). When ${ }^{125}$ I was injected into peritoneal tissues of mice and subsequent scintigraphy was performed at 4 months, accumulation of radioiodide was evident in tumors derived from FRTL (RET/PTC1) cells (Fig. 3B). Figure $3 \mathrm{C}$ and D show macroscopic and microscopic views respectively of a tumor derived from injected FRTL (RET/PTC1) cells. Histologically, this solid tumor had a partially glandular structure, and the tumor cells invaded into the surrounding skeletal muscles.

We then further transfected pSilencer ( $T t f 1$ into FRTL (RET/PTC1) cells and established stable cell lines (FRTL (RET/PTC1)-siTtf1 by selecting with G418. When expression of Ttf1 in FRTL (pcDNA) cells was set to 1.0, the level of Ttf1 mRNA in FRTL (RET/PTC1)-siTtf1 cells was $0.81 \pm 0.042$ and not significantly different from that in FRTL (pcDNA) cells.

To investigate the role of TTF1 in tumorigenicity, FRTL (RET/PTC1)-siTtf1 cells were injected into the subcutaneous tissues of the backs of nude mice $(n=9)$. Even 4 months after injection of the cells, no tumor formation was evident at any of the nine injection sites (Table 2).

\section{Effects of TTF1 on the human thyroid papillary cancer cell line BHP18-21v}

BHP18-21v cells are derived from a PTC, and they express RET/PTC1. They also express PAX8 but not TTF1 or TG. Previously, we found that adenovirus-mediated transfer of $T t f 1$ into BHP18-21v cells induces re-expression of $T G$ and TPO (Furuya et al. 2004). However, expression of TTF1 via this method is transient; therefore, we introduced pcDNAzeo-hTTF1 into BHP18-21v cells to generate BHP18-21v (TTF1) cells that stably express TTF1. We then used BHP18-21v (pcDNA) and BHP18-21v (TTF1)

Published by Bioscientifica Ltd. 

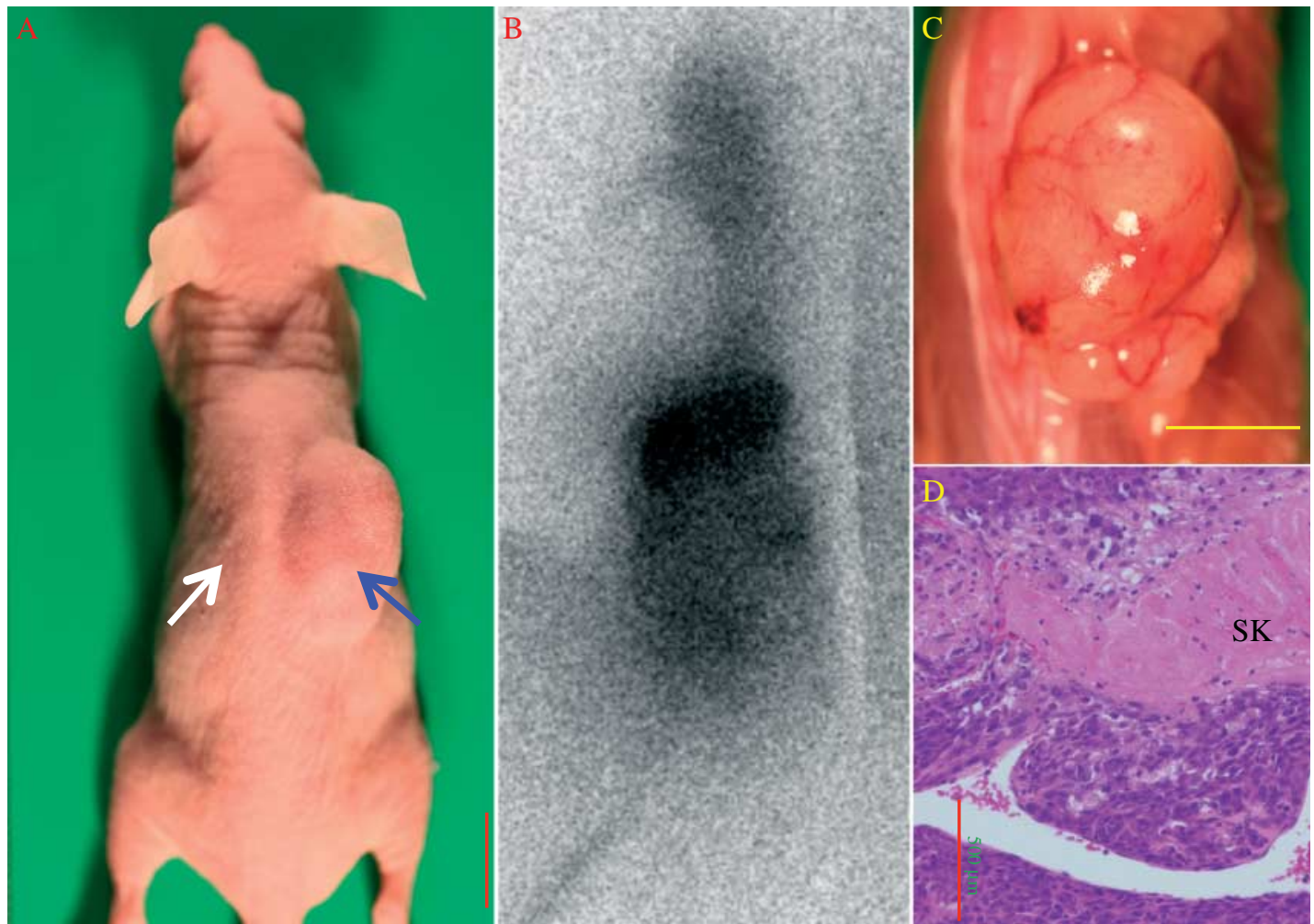

\section{Figure 3}

Tumor formation from FRTL (RET/PTC1) cells injected into nude mice. (A) Tumor formation from FRTL (RET/PTC1) cells. FRTL (RET/PTC1) cells ( $10^{6}$ cells) or FRTL ( $\left.p c D N A\right)$ cells $\left(10^{6}\right.$ cells) were transplanted into the subcutaneous tissues of the right (blue arrow) back and the left (white arrow) back respectively of a nude mouse. Two months after transplantation, a tumor had formed on the right side of the back at the

cells to study the effect of TTF1 on tumorigenicity. Quantitative PCR using the plasmid as a standard revealed that $(6.2 \pm 0.62) \times 10^{5}$ copies/ $\mu$ g RNA of TTF1 $(n=3)$ were transfected into BHP18-21v (TTF1) cells. When TTF1 expression in normal human thyroid glands was defined as 1.0, TTF1 expression in BHP18-21v (TTF1) cells was $0.84 \pm 0.06$. Expressions of $T G$ and $T P O$ genes were undetectable in BHP18-21v (pcDNA), but these genes were re-expressed at $(0.51 \pm 0.06)(n=3)$ and $(0.28 \pm 0.03)$ $(n=3)$ respectively in BHP18-21v (TTF1) cells (Fig. 4A).
(FRTL (RET/PTC1) cell injection site). (B) ${ }^{125}$ I scintigraphy of the tumor. $\mathrm{Na}^{125}$ | $\left(5 \times 10^{6}\right.$ c.p.m. $)$ was injected into the peritoneal space, and $6 \mathrm{~h}$ later, radioactivity was imaged by exposing the back to an imaging plate. ${ }^{125} \mathrm{I} \mathrm{had}$ accumulated on the right side back. (C and D) Macroscopic (C, bar: $1 \mathrm{~cm})$ and microscopic ( $D$, hematoxylin-eosin staining; scale bar, $500 \mu \mathrm{m})$ features of the tumor derived from FRTL (RET/PTC1) cells. SK, skeletal muscle.

But, TTF1 showed little effect on NIS or TSHR gene expression in stably transfected cells as was observed in the transiently transfected cells BHP18-21v (Ad-TTF1) (Furuya et al. 2004). There was no significant difference in cell growth (Fig. 4B) or in BrdU incorporation (Fig. 4C) between BHP18-21v (pcDNA) and BHP18-21v (TTF1) cells. TTF1 also showed little effect on the morphology of BHP18-21v cells (Fig. 4D and E).

To investigate the effect of co-expression of TTF 1 and RET/PTC1 on the tumorigenicity of BHP18-21v cells,

Table 2 Tumorigenicity of FRTL5 cells in nude mice

\begin{tabular}{|c|c|c|}
\hline & Ttf1 expression & $\begin{array}{l}\text { Tumor formation at } \mathbf{2} \mathbf{M} \text { (mean of } \\
\text { maximum diameter of tumors }(\mathrm{mm}) \text { ) }\end{array}$ \\
\hline FRTL5 (pcDNA) & 1.0 & $0 / 10$ \\
\hline FRTL5 (RET-PTC1) & $4.68 \pm 0.34^{*, a}$ & $6 / 10 *(8.2 \pm 1.1) *$ \\
\hline FRTL5 (RET-PTC1) + pSilenc-TTF1 & $0.81 \pm 0.042^{a}$ & $0 / 9$ \\
\hline
\end{tabular}

$\begin{gathered}\text { Tumor formation at } \mathbf{4 M}(\text { mean of } \\ \text { maximum diameter of tumors }(\mathrm{mm}))\end{gathered}$
$0 / 9$
$9 / 9 *(24 \pm 4.5)^{*}$
$0 / 9$

Data are mean + s.E.M. of three independent experiments. ${ }^{*} P<0.001$ vs FRTL5 (pCDNA).

${ }^{a}$ Expression of TTF1 mRNA in FRTL (pcDNA) cells was set as 1.0.

http://erc.endocrinology-journals.org
DOI: $10.1530 / E R C-13-0310$
(C) 2013 The authors Printed in Great Britain
Published by Bioscientifica Ltd 


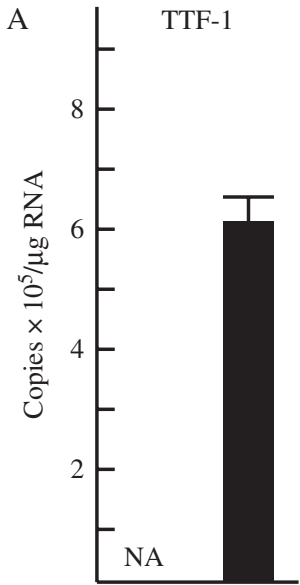

$18-21 \mathrm{v} \quad 18-21 \mathrm{v}$ (pcDNA) (TTF1)

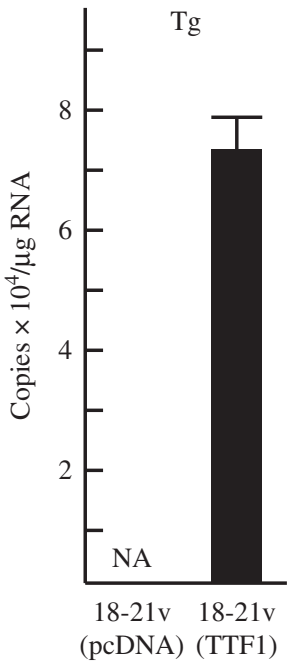

B

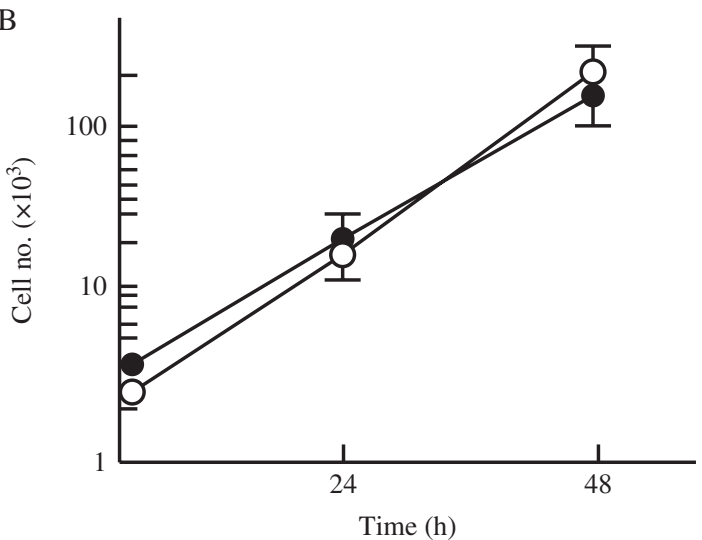

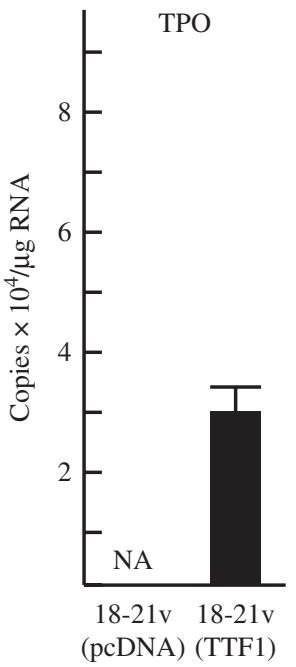
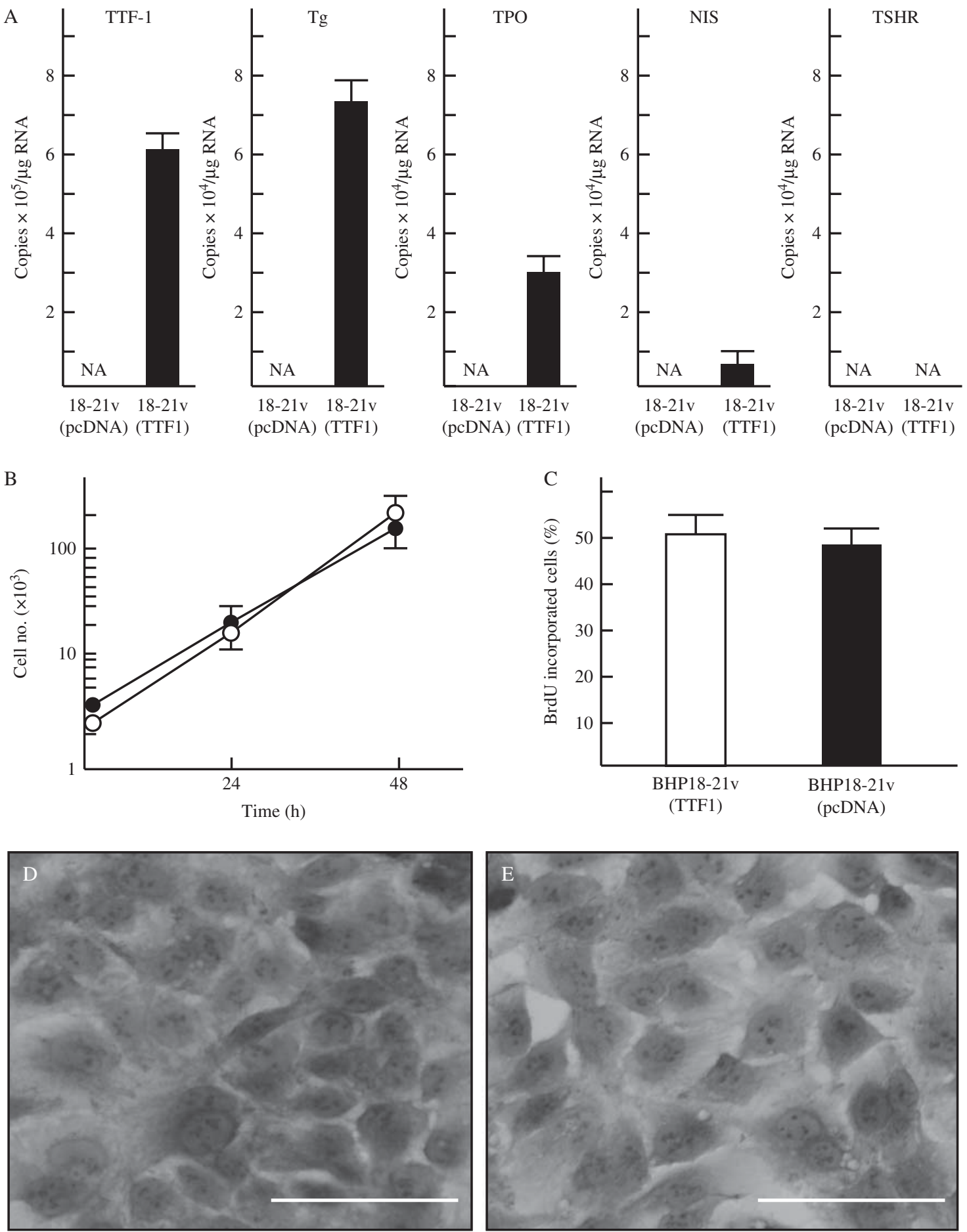

\section{Figure 4}

Effects of TTF1 on thyroid-specific gene expression in, cell growth of and, morphology of BHP18-21v cells. (A) Effects of TTF1 on thyroid-specific gene expression in BHP18-21v cells. pcDNAzeo-hTTF1 was stably transfected into BHP18-21v cells, and expression levels of five thyroid-specific genes (TTF1, $T G, T P O, N I S$, and TSHR) in the cells were determined by quantitative PCR. Expression of each gene of interest in human thyroid glands was normalized to that of GAPDH, and these values were set as 1.0 for comparisons with

http://erc.endocrinology-journals.org DOI: 10.1530/ERC-13-0310
(C) 2013 The authors Printed in Great Britain expression in BHP18-21v (pcDNA) cells or BHP18-21v (TTF1) cells. NA, no product could be amplified. (B) Growth curves of BHP18-21v (TTF1) (open circle-open circle: $n=3$ ) cells and of BHP18-21v (pcDNA) cells (closed circleclosed circle: $n=3$ ). (C) Incorporation of BrdU into BHP18-21v (TTF1) $(n=3$; open column) cells or into BHP18-21v (pcDNA) cells ( $n=3$; closed column) $48 \mathrm{~h}$ after addition of BrdU. Microscopic views of BHP18-21v (pcDNA) cells (D) or BHP18-21v (TTF1) cells (E). Scale bars, $100 \mu \mathrm{m}$. 


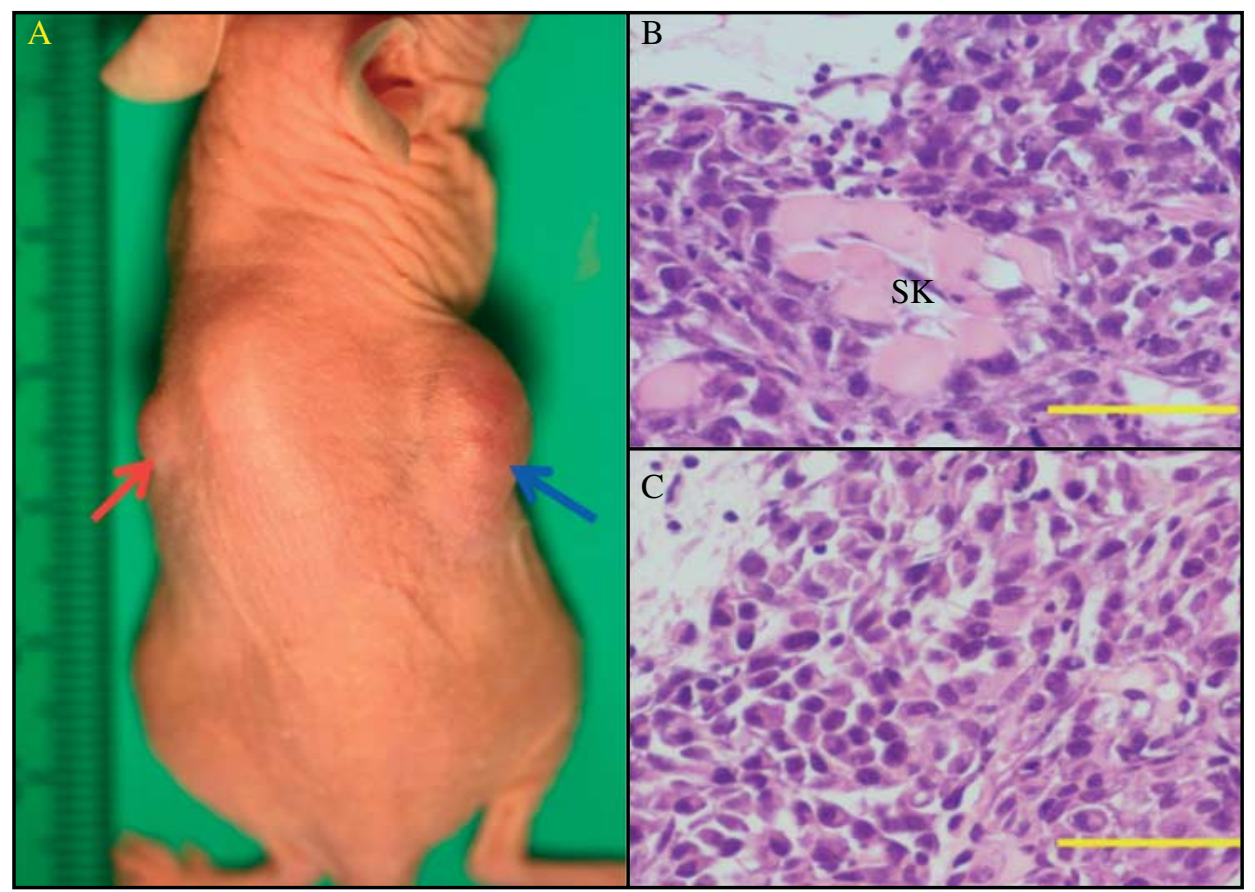

\section{Figure 5}

Transplantation of BHP18-21v (TTF1) cells into subcutaneous tissue of nude mice. (A) Macroscopic view of tumors formed by BHP18-21v (TTF1) cells (blue arrow) and by BHP18-21v (pcDNA) cells (red arrow). (B and C)

we transplanted BHP18-21v (TTF1) cells into subcutaneous tissues on the right side and BHP18-21v (pcDNA) cells on the left sides of the backs of Balb/c nude mice. After 2 weeks, tumor formation was evident at the site of BHP18-21v (TTF1) cells injection in each of the eight mice, but not one mouse had a tumor form at the site of BHP18-21v (pcDNA) cell injection. After 4 weeks, all mice $(n=8)$ had developed a large solid mass at the site of BHP18-21v (TTF1) cell injection, and the mean of the maximum tumor diameter was $25 \pm 5.5 \mathrm{~mm}$ (Fig. $5 \mathrm{~A}$ and Table 3). At this 4-week time point, three of the eight mice had developed a tumor at the site of BHP18-21v (pcDNA) cell injection, and the mean of the maximum tumor diameter was $8 \pm 2.1 \mathrm{~mm}$ for these three tumors. Notably, the mean of the maximum tumor diameter was significantly larger $(P<0.01)$ for the BHP18-21v (TTF1) tumors than for the BHP18-21v (pcDNA) tumors. Figure 5A, B, and $\mathrm{C}$ shows macroscopic and microscopic views of tumors derived from injected BHP18-21v (TTF1) and BHP18-21v (pcDNA) cells. Histologically, no glandular structure was observed in tumors from BHP18-21v (TTF1) or from BHP18-21v (pcDNA) cells. Notably, BHP18-21v (TTF1) cells had infiltrated into surrounding skeletal muscles within 4 weeks, but BHP18-21v (pcDNA) cells had not.
Microscopic views of tumors formed by BHP18-21v (TTF1) cells (B) and by BHP18-21v (pcDNA) cells (C). Scale bars, $20 \mu \mathrm{m}$. SK, skeletal muscle.

\section{Discussion}

We used FRTL5 cells for this study because these cells express almost every thyroid-specific gene - including $T g$, Nis, and Tshr, as well as the thyroid-specific transcription factors, Ttf1, Ttf2, and Pax8 (Santisteban et al. 1987). Expression of RET/PTC1 in FRTL5 cells caused nuclei to become irregularly shaped and cell proliferation to become independent of TSH. These changes indicated that expression of RET/PTC1 was sufficient to cause FRTL5 cells to develop malignant phenotypes.

Additionally, De Vita and colleagues expressed RET/PTC1 in PC Cl cells, another line of rat thyroid

Table 3 Tumorigenicity of BHP19-21v cell derivatives in nude mice

\begin{tabular}{|c|c|c|c|}
\hline & $\begin{array}{l}\text { Tumor forma- } \\
\text { tion at } \mathbf{2} \text { weeks } \\
\text { (mean of maxi- } \\
\text { mum diameter } \\
\text { of tumors }(\mathrm{mm}) \text { ) }\end{array}$ & $\begin{array}{l}\text { Tumor forma- } \\
\text { tion at } \mathbf{3} \text { weeks } \\
\text { (mean of maxi- } \\
\text { mum diameter of } \\
\text { tumors }(\mathrm{mm}) \text { ) }\end{array}$ & $\begin{array}{l}\text { Tumor forma- } \\
\text { tion at } 4 \text { weeks } \\
\text { (mean of maxi- } \\
\text { mum diameter } \\
\text { of tumors }(\mathrm{mm}) \text { ) }\end{array}$ \\
\hline $\begin{array}{r}\text { BHP18-21v } \\
(p c D N A)\end{array}$ & $0 / 8$ & $1 / 8$ & $3 / 8(8.1 \pm 2.1)$ \\
\hline $\begin{array}{l}\text { BHP18-21v } \\
\text { (TTF1) }\end{array}$ & $8 / 8 *(12.3 \pm 2.4) *$ & $8 / 8 *(17.8 \pm 3.9) *$ & $8 / 8 *(25.0 \pm 5.5) *$ \\
\hline 001 & HP18-21v (pcDNA). & & \\
\hline
\end{tabular}


epithelial cells. Pax8 expression was significantly lower in $\mathrm{PC} \mathrm{Cl}$ (RET/PTC1) cells than in the parental PC Cl cells, but TTF1 expression was essentially unaltered by RET/PTC1 expression; function of TTF1 might be inactive (De Vita et al. 1998). By contrast, we demonstrated that RET/PTC1 increased the expression of Ttf1, Tg, and Nis in FRTL5 cells, but RET/PTC1 had little or no effect on Ttf2 and Pax8 expression. These results indicated that TTF1 functions in FRTL5 cells. Therefore, the results reported by De Vita et al. seem to conflict with our findings.

FRTL5 and PC Cl cells present similar sets of properties, including i) TSH-dependent growth and differentiated functions, ii) iodine-uptake, and iii) $T g$ and $T p o$ gene transcription. The transformation of $\mathrm{PC} \mathrm{Cl}$ cells requires a combination of two retroviral oncogenes, but one oncogene is sufficient to fully transform FRTL5 cells; this difference indicates that FRTL5 cells may intrinsically express some oncogenic function that contribute to a fully malignant phenotype, but $\mathrm{PC} \mathrm{Cl}$ cells may lack this function (Fusco et al. 1987). Although the discrepancy between our results and those of De Vita remains unresolved, it might due to a difference in the precancerous condition of PC Cl cell and that of FRTL5 cells.

TTF1 is a master regulator of the expression of $T g$ and NIS (Sinclair et al. 1990, Endo et al. 1997), and increased levels of $T g$ and Nis in FRTL (RET/PTC1) cells might be due to increased expression of TTF1. Indeed, when FRTL (RET/PTC1) cells were transplanted into the subcutaneous tissue of nude mice, the resulting tumor cells retained ${ }^{125}$ I-uptake activity, as do some human papillary thyroid cancer tissues. These findings were consistent with the findings that human PTCs that expressed RET/PTC1 maintained NIS gene expression, but those that expressed $\mathrm{BRAF}^{\mathrm{V600E}}$ did not (Romei et al. 2008).

It is of particular interest that FRTL (RET/PTC1) cells were tumorigenic in nude mice, in spite of the fact that FRTL (pcDNA) cells were not. Further, when TTF1 gene expression was silenced by siTTF1, FRTL (RET/PTC1) cells failed to form tumors in nude mice. Similarly, TTF1 was also important to the tumorigenicity of BHP18-21v cells. These cells lacked intrinsic TTF1 expression; however, stable expression of TTF1 from a transgenic expression construct increased $T G$ and TPO mRNA levels in cultures of these cells; moreover, transgenic expression of TTF1 enhanced tumorigenicity of these cells when they were transplanted into nude mice. These results indicated that the oncoprotein, RET/PTC1, and the thyroid-specific transcription factor, TTF1, might interact and consequently affect the tumorigenicity of PTCs.
Therefore, our present results might provide a new insight into the roles of the oncoprotein, RET/PTC1, and thyroid-specific transcription factor, TTF1, in the pathogenesis of PTCs.

\section{Declaration of interest}

The authors declare that there is no conflict of interest that could be perceived as prejudicing the impartiality of the research reported.

\section{Funding}

This research did not receive any specific grant from any funding agency in the public, commercial or not-for-profit sector.

\section{References}

De Vita G, Zannini M, Cirafici AM, Melillo RM, Di Lauro R, Fusco A \& Santoro M 1998 Expression of the RET/PTC1 oncogene impairs the activity of TTF-1 and Pax-8 thyroid transcription factors. Cell Growth \& Differentiation 9 97-103.

Endo T \& Kobayashi T 2010 Runx2 deficiency in mice causes decreased thyroglobulin expression and hypothyroidism. Molecular Endocrinology 24 1267-1273. (doi:10.1210/me.2010-0056)

Endo T, Shimura H, Saito T \& Onaya T 1990 Cloning of malignantly transformed rat thyroid (FRTL) cells with thyrotropin receptors and their growth inhibition by $3^{\prime}, 5^{\prime}$-cyclic adenosine monophosphate. Endocrinology 126 1492-1497. (doi:10.1210/endo-126-3-1492)

Endo T, Kaneshige M, Nakazato M, Kogai T, Saito T \& Onaya T 1996 Autoantibody against thyroid iodide transporter in the sera from patients with Hashimoto's thyroiditis possesses iodide transport inhibitory activity. Biochemical and Biophysical Research Communications 228 199-202. (doi:10.1006/bbrc.1996.1639)

Endo T, Kaneshige M, Nakazato M, Ohmori M, Harii N \& Onaya T 1997 Thyroid transcription factor-1 activates the promoter activity of rat thyroid $\mathrm{Na}^{+} / \mathrm{I}^{-}$symporter gene. Molecular Endocrinology 11 1747-1755. (doi:10.1210/me.11.11.1747)

Fugazzola L, Puxeddu E, Avenia N, Romei C, Cirello V, Cavaliere A, Faviana P, Mannavola D, Moretti S, Rossi S et al. 2006 Correlation between B-RAFV600E mutation and clinico-pathologic parameters in papillary thyroid carcinoma: data from a multicentric Italian study and review of the literature. Endocrine-Related Cancer 13 455-464. (doi:10.1677/erc.1.01086)

Furuya F, Shimura H, Miyazaki A, Taki K, Ohta K, Haraguchi K, Onaya T, Endo T \& Kobayashi T 2004 Adenovirus-mediated transfer of thyroid transcription factor-1 induces radioiodide organification and retention in thyroid cancer cells. Endocrinology 145 5397-5405. (doi:10.1210/ en.2004-0631)

Fusco A, Berlingieri MT, Di Fiore PP, Portella G, Grieco M \& Vecchio G 1987 One- and two-step transformations of rat thyroid epithelial cells by retroviral oncogenes. Molecular and Cellular Biology 7 3365-3370.

Gudmundsson J, Sulem P, Gudbjartsson DF, Jonasson JG, Sigurdsson A, Bergthorsson JT, He H, Blondal T, Geller F, Jakobsdottir M et al. 2009 Common variants on $9 \mathrm{q} 22.33$ and $14 \mathrm{q} 13.3$ predispose to thyroid cancer in European populations. Nature Genetics 41 460-464. (doi:10.1038/ng.339)

Knostman KA, Venkateswaran A, Zimmerman B, Capen CC \& Jhiang SM 2007 Creation and characterization of a doxycycline-inducible mouse model of thyroid-targeted RET/PTC1 oncogene and luciferase reporter gene coexpression. Thyroid 17 1181-1188. (doi:10.1089/thy. 2007.0224)

Published by Bioscientifica Ltc. 
Kolla V, Gonzales LW, Gonzales J, Wang P, Angampalli S, Feinstein SI \& Ballard PL 2007 Thyroid transcription factor in differentiating type II cells: regulation, isoforms, and target genes. American Journal of Respiratory Cell and Molecular Biology 36 213-215. (doi:10.1165/rcmb. 2006-0207OC)

Melillo RM, Castellone MD, Guarino V, De Falco V, Cirafici AM, Salvatore G, Caiazzo F, Basolo F, Giannini R, Kruhoffer M et al. 2005 The RET/PTCRAS-BRAF linear signaling cascade mediates the motile and mitogenic phenotype of thyroid cancer cells. Journal of Clinical Investigation 115 1068-1081.

Mizutori Y, Chen CR, McLachlan SM \& Rapoport B 2008 The thyrotropin receptor hinge region is not simply a scaffold for the leucine-rich domain but contributes to ligand binding and signal transduction. Molecular Endocrinology 22 1171-1182. (doi:10.1210/me.2007-0407)

Nikiforov YE \& Nikiforova MN 2011 Molecular genetics and diagnosis of thyroid cancer. Nature Reviews. Endocrinology 7 569-580. (doi:10.1038/ nrendo.2011.142)

Nikiforov YE, Rowland JM, Bove KE, Monforte-Munoz H \& Fagin JA 1997 Distinct pattern of ret oncogene rearrangements in morphological variants of radiation-induced and sporadic thyroid papillary carcinomas in children. Cancer Research 57 1690-1694.

Ohta K, Pang XP, Berg L \& Hershman JM 1997 Growth inhibition of new human thyroid carcinoma cell lines by activation of adenylate cyclase through the $\beta$-adrenergic receptor. Journal of Clinical Endocrinology and Metabolism 182 2633-2638. (doi:10.1210/jc.82.8.2633)

Pritchard C, Carragher L, Aldridge V, Giblett S, Jin H, Foster C, Andreadi C \& Kamata T 2007 Mouse models for BRAF-induced cancers. Biochemical Society Transactions 35 1329-1333. (doi:10.1042/BST0351329)

Romei C, Ciampi R, Faviana P, Agate L, Molinaro E, Bottici V, Basolo F, Miccoli P, Pacini F, Pinchera A et al. 2008 BRAFV600E mutation, but not RET/PTC rearrangements, is correlated with a lower expression of both thyroperoxidase and sodium iodide symporter genes in papillary thyroid cancer. Endocrine-Related Cancer 15 511-520. (doi:10.1677/ ERC-07-0130)
Santisteban P, Kohn LD \& Di Lauro R 1987 Thyroglobulin gene expression is regulated by insulin and insulin-like growth factor I, as well as thyrotropin, in FRTL-5 thyroid cells. Journal of Biological Chemistry 262 4048-4052.

Santoro M, Chiappetta G, Cerrato A, Salvatore D, Zhang L, Manzo G, Picone A, Portella G, Santelli G, Vecchio G et al. 1996 Development of thyroid papillary carcinomas secondary to tissue-specific expression of the RET/PTC1 oncogene in transgenic mice. Oncogene 12 1821-1826.

Silberschmidt D, Rodriguez-Mallon A, Mithboakar P, Calì G, Amendola E, Sanges R, Zannini M, Scarfò M, De Luca P, Nitsch L et al. 2011 In vivo role of different domains and of phosphorylation in the transcription factor Nkx2-1. BMC Developmental Biology 11 9. (doi:10.1186/ 1471-213X-11-9)

Sinclair AJ, Lonigro R, Civitareale D, Ghibelli L \& Di Lauro R 1990 The tissue-specific expression of the thyroglobulin gene requires interaction between thyroid-specific and ubiquitous factors. European Journal of Biochemistry 193 311-318. (doi:10.1111/j.1432-1033.1990.tb19339.x)

Vitti P, Rotella CM, Valente WA, Cohen J, Aloj SM, Laccetti P, AmbesiImpiombato FS, Grollman EF, Pinchera A, Toccafondi R et al. 1983 Characterization of the optimal stimulatory effects of Graves' monoclonal and serum immunoglobulin $\mathrm{G}$ on adenosine $3^{\prime}, 5^{\prime}$-monophosphate production in fRTL-5 thyroid cells: a potential clinical assay. Journal of Clinical Endocrinology and Metabolism $\mathbf{5 7}$ 782-791. (doi:10.1210/jcem-57-4-782)

Xing M, Westra WH, Tufano RP, Cohen Y, Rosenbaum E, Rhoden KJ, Carson KA, Vasko V, Larin A, Tallini G et al. 2005 BRAF mutation predicts a poorer clinical prognosis for papillary thyroid cancer. Journal of Clinical Endocrinology and Metabolism 90 6373-6379. (doi:10.1210/jc.2005-0987)

Zou M, Shi Y \& Farid NR 1994 Low rate of ret proto-oncogene activation (PTC/retTPC) in papillary thyroid carcinomas from Saudi Arabia. Cancer 73 176-180. (doi:10.1002/1097-0142(19940101)73:1<176::AIDCNCR2820730130>3.0.CO;2-T)

Received in final form 31 August 2013

Accepted 4 September 2013

Made available online as an Accepted Preprint

4 September 2013 (c) 2013 The authors Printed in Great Britain
Published by Bioscientifica Ltd. 